\title{
EU Research Policy as a Transnational Memory Policy Instrument? The Framework Programmes and the Production of Competing Visions of Europe
}

\author{
Morgane Le Boulay \\ CNRS/University of Strasbourg Laboratory SAGE (Societies, Actors and Governement in \\ Europe), France
}

\begin{abstract}
This article considers the history-based research networks funded by the Framework Programmes for Research and Technological Development (FPs). It sheds light on the interactions between the European Commission and scholars - Commission-appointed experts, funded researchers, but also scholars who disagree with the EU memory policy. Even if the scholars' influence is significant, the FPs remain an instrument in the hands of the European Commission. The visions of the history of Europe brought forward are in conformance with official narratives highlighted by works on other EU memory policy instruments. This leads to a confrontation between "authorised" and alternative narratives at European level. While the institutionalisation of European research networks as a form of knowledge production which is intended to be specifically European contributes to shaping "Europe", the idea of the emergence of an autonomous "European memory space" nevertheless deserves nuancing because of the FPs' fragmented nature and of the role that national academic levels continue to play.
\end{abstract}

\section{Keywords}

European identity, European Union, framework programmes for research and technological development, knowledge production, memory policy, research policy, transnational memory space

\section{Acknowledgments}

This article was edited by Jean-Yves Bart, with support from the Maison Interuniversitaire des Sciences de l'Homme d'Alsace (MISHA) and the University of Strasbourg's Initiative of Excellence. I would like to thank Carlos Closa (Instituto Universitario Ortega y Gasset, Madrid) for having organised a workshop on EU politics of memory in Florence in June 2015, Aline Sierp (Maastricht University) and Jenny Wüstenberg (Nottingham Trent University) for having organised a workshop on agency in translational memory politics in Philadelphia in April 2016, as well as Jennifer Dixon (Villanova University, Pennsylvania), Andrea Hepworth (Victoria University of Wellington) and the anonymous peer reviewers for their thoughtful comments on previous versions of this article. I also would like to thank Wilfried Loth, Henry Rousso and Jean-Frédéric Schaub, with whom I could exchange emails or conduct interviews.

\section{Introduction}

A growing number of studies (see especially Bond and Rapson, 2014; de Cesari and Rigney, 2014; Erll, 2011; Erll and Rigney, 2018; Sierp and Wüstenberg, 2015) highlight the increasing role of supranational levels and transnational dynamics in the shaping of memory narratives. The EU memory policies, in particular, which began to develop in the 1970s and have gained momentum since the 1990s, have been the subject of research in this vein (Calligaro, 2013; Gensburger and Lavabre, 2012; Larat, 2005; Le Boulay, 2014; Littoz Monnet, 2013; Mink and Neumayer, 2007; Neumayer, 2019; Rigney, 2014; Sierp, 2014). However, this body of literature is mainly focused on European Parliament resolutions or EU Council decisions in the field of memory, commemoration days, funding of past-oriented cultural projects and historical references in official texts like Treaties. Quite a few authors (Calligaro, 2013: 38-77; Le 
Boulay, 2010; Mangenot and Schirman, 2012) have considered the actions specifically designed to encourage the writing of European integration history, in particular the European Commission's support to historians who have specialised in this field - within the European University Institute's (EUI) department of history since 1976 or within the European Union Liaison Committee of Historians (thereafter "Liaison Committee") since 1982. The contribution of EU research policy to EU memory policy has nevertheless not been further explored. Indeed, memory studies widely rest on the distinction between history (referring to a scientific discipline and its methods) and memory (referring to non-scientific uses of the past). Yet, the role of history writing as lieu de mémoire has largely been highlighted in national configurations (notably by Nora, 1986: 185-429), and the aforementioned publications indicate that this way of shaping representations of the past has been re-appropriated at European level. This in turn raises the question of the extent to which European research funding is allocated to history-based projects, and the extent to which this is part of a memory policy. Furthermore, the relationship between this policy and the scientific field deserves to be examined: How do they mutually influence each other? To what extent does European research funding lead to conflicts between competing visions of European history?

This article addresses these questions by focusing on the Framework Programmes for Research and Technological Development (FPs). This research funding system, initially founded in 1984 for the "exact sciences", has financed projects on historical topics since 2001. Every few years, the European institutions (primarily the European Commission, but also the European Parliament and the EU Council) define the EU's research strategy (Andersen, 2017: 50-54). This includes setting the FPs' thematic priorities (now called "Societal Challenges"), which make up the bulk of the funding among the various FP schemes. With the help of expert groups composed of academic, public and private actors - in particular, "Expert Advisory Groups" (EAG) appointed for each thematic priority -, the European Commission's Directorate-General for Research and Innovation (DG RTD) then launches work programmes including calls for proposals that specify the topics for each thematic priority under which international and interdisciplinary research teams can apply, and selects projects for subsidies. Thus, even if "comitology committees" composed of representatives of Members States are asked to provide their opinion on the draft work programmes, the FPs break up the States' monopoly over the definition of relevant scientific subjects. Health, environment, communication technologies, and energy were the priorities of the five first FPs (1984-2002). Researchers in the humanities and social sciences could only apply within other, less significant parts of these Programmes. That is how the first history-based projects were funded by the fifth FP (FP5, 1998-2002) within an action aimed at "Improving the human research potential and the socio-economic knowledge base". Yet, the following Programmes integrated human and social sciences themes into their thematic priorities: "Citizens and Governance in a Knowledge-Based Society" (FP6, 2002-2006), "Socio-economic Sciences and Humanities" (FP7, 2007-2013), and "Europe in a Changing World - Inclusive, Innovative and Reflective Societies" (FP8, called "Horizon 2020" or H2020, 2014-2020).

The funds devoted to these themes were certainly very meagre in comparison with the other thematic priorities. Still, because of their large and ever-increasing budget, which makes it the largest funding instrument for research worldwide (Andersen, 2017: 51; Kustosz, 2012: 26), the FPs have become a crucial structure in the research landscape, amounting to millions of Euros for social sciences. Admittedly, because of a problem-solving logic which favours projects which can help in implementing European policies (Kustosz, 2012), most of the projects selected within the aforementioned thematic priorities have been led by political scientists, sociologists, jurists and economists dealing with current matters rather than historical topics. Nonetheless, by performing a keyword search using terms like history, memory or past 
and examining project presentations, I was able to identify 34 research networks with a historical component which have been funded since FP5 (cf. Table 1). Moreover, the European Commission (2010) actually considers the FPs as a EU memory policy instrument. Concerning "the memory of the crimes committed by totalitarian regimes in Europe", they are the second means of action identified by the Commission (p. 8) after the "Europe for Citizens" programme, which promotes understanding between the EU and its citizens, in particular by financing projects in the field of memory. This raises the question of the narratives brought forward in the FPs. Does an official view of history emerge? Particularly informative sources in that respect are the texts of the calls, which were initially brief, but have become more elaborate over the successive FPs, as well as the presentations and reports on selected projects, all available on the website of the Community Research and Development Information Service (CORDIS). ${ }^{1}$

While many authors have not only examined the role of the EU institutions, but also of EU Member States, the Council of Europe, journalists, museums, religious actors or historians in shaping visions of the European past (especially Calligaro, 2013, 2014; Gensburger, 2008; Gensburger and Lavabre, 2012; Mazé, 2014; Mink and Neumayer, 2007; Pakier and Stråth, 2010), studying the FPs can particularly improve our understanding of the interactions between the European Commission and scholars, especially historians. This article does not claim to analyse all aspects of this question. In particular, it does not examine the actual project selection process. However, it questions the impact of the FPs' calls on scholars and, conversely, the power of scholars to alter the FPs. To what extent do historians or other scholars contribute to the memory policy which emerges from the FPs? How do historians who disagree with the utilitarian vision of historical research and/or the representations of history promoted by the FPs react? As regards FP7 and H2020, in addition to the aforementioned documents available on the CORDIS website, I was able to consult the list of the experts involved in the design of calls and their reports, the list of experts involved in project selection (without mention of the specific calls in which they were involved), as well as the acronyms, the titles and the (very short) abstracts of the rejected project proposals. However, because of the legislation regarding the protection of personal data, the European Commission refused to provide me with the names of the unsuccessful applicants. Moreover, additional documents concerning FP5 and FP6 were unavailable, as they are kept for only 10 years (DG RTD official, 2019, personal communication). Last but not least, administrative documents, while valuable, are insufficient to examine the link between the FP's policy and researchers or, more importantly, to confront official and non-official narratives. Additional research methods should thus be used. Since the experts have a duty of confidentiality regarding their expertise activity for the FPs, I interviewed and exchanged emails with FP-funded scholars as well as unsuccessful applicants, and examined their career paths. By doing so, I was able to consider academic proponents of different scientific approaches. As a result, this article may improve our understanding of how the FPs have been jointly shaped by various actors, but also of the conflicts between these actors' representations of Europe.

The first section analyses the research networks funded by FP5 and FP6. It highlights a funding policy with a clear outline, namely the search for European long-term history and "identity", as well as the fact that this policy reflects both political and scientific concerns. The second section examines the way in which FPs affect work on the past, especially on European history. It does not only focus on funded projects, but also on scholars whose approach does not match the European Commission's expectations and who decide to counter official narratives with their own networks and publications. By considering the FPs transformations from FP7 onwards, the last section questions the scholars' ability to change this funding system - whether they were appointed as experts or not. Ultimately, this study leads to question, in the conclusion, the shaping of "Europe" and its representations through a specific instrument of knowledge 
production (international research networks) as well as its particularities in comparison with national vision-shaping, especially in terms of the development of a transnational memory space: To what extent can we argue that such a thing exists; if so, what would it mean and what is the place of FPs in this framework?

\section{A clear outline: The search for a European long-term history and "identity"}

Until 2001, the European Commission's actions regarding history were almost exclusively dedicated to the political integration process. In the scientific field in particular, every historybased project funded by the Commission dealt, at least in part, with this contemporary process. These actions essentially rested on the relationship with successive EUI historians who worked on European integration and with the "Liaison Committee", but also with Jean Monnet Chairholders, even though these chairs primarily focus on history teaching (Le Boulay, 2010, 2014: 64-11, 199-213). A turning point occurred in 2001 with FP5. Admittedly, the FPs remained (like other EU memory policy instruments) principally focused on "European history" - since then, only one history-based funded network has not pertained to "Europe" (URBACHINA, funded from 2011 as part of a special call for proposals on the urbanisation of China). They also continued to support the history of European political integration. Both FP5 and FP6, especially, funded networks which included "Liaison Committee" members: EI HISTORY, analysing historical archives from the 1960s and 1970s which were being opened to the public at that time, and EU-CONSENT, on the EU's enlargement and deepening process since 1973. Nonetheless, the FPs favoured a wider definition of "European integration" by financing a project on the "European public space" since the Treaty of Rome (EMEDIATE), and another on the role of churches in the Cold War, but also in European integration (CEI). They also promoted a wider definition of "Europe" by funding projects on subjects other than the integration process (and actors other than elites): the "European civil society" (CiSoNet), migrations of women in Europe (GRINE), "domestic service as a factor of European identity" (SERVANT PROJECT), the "political cultures of the small West European states" (Smallcons) and the Euro-Mediterranean area (REMSH, RAMSES II).

The teams working on the three latter networks and CLIOHRES.NET (which aimed at rethinking the writing of history in the context of a "Growing Europe") included not only specialists in contemporary history, but also modernists - as well as researchers from other social sciences, as FP-funded projects are expected to be multi-disciplinary. CLIOHRES.NET and RASMES II even included medievalists, and ancient historians for the latter. Besides, scientific institutions from non-EU countries (candidate countries as well as Switzerland) participated in almost every network from FP5, and non-European academics joined the networks during FP6 (cf. Table 1). Since several of the aforementioned projects emphasised their historical take on the concept of "European identity", they contributed to the idea that such an "identity" exists, that (long-term) history and its perception are a significant part of it, and that it is not limited to the EU Member States or the elites. Which historical developments and which actors, however, led the FPs to endorse the search for this "European identity" in the years following 2000 ?

On the political level, the EU's successive enlargements to the East from 2004 played a very important role. Firstly, they explain the participation of scientific institutions from candidate countries. Secondly, they influenced the substance of the funded projects. Not only were several calls for proposals explicitly focused on the enlargements, but these enlargements also brought the EU closer to continental Europe. As a result, different takes on European history could be considered part of the EU's history - no longer only the contemporary history of the construction of a political and economic Europe with clear borders, but also the long history of 
an open Europe, taking social and cultural aspects into account. This particularly transpires in the FP6 calls, which refers to "European society" and to the relationships between new borders and "European identities".

Since the European Parliament expanded to include members from new Eastern Member States in 2004, its resolutions on history have considered the past of these countries (Perchoc, 2014: 214). This indicates a shift within different EU memory policies in the context of the enlargements. A comparison with the Council of Europe's memory policies also suggests transfers in this context. Indeed, the Council of Europe, which began bringing in Eastern European countries in 1990, has favoured an inclusive, albeit somewhat vague conception of European history, "identity", and "heritage" through its cultural policy since the 1950s and through its education policy since 1989 (Calligaro, 2014: 65; Le Boulay, 2014: 150, 284). Like the EU's cultural actions (Calligaro, 2014), its research policy appears to have been influenced by this conception when the enlargements brought the EU closer to the Council of Europe.

Still regarding the political level, the Euro-Mediterranean Partnership in 1995 may explain the funding of projects on this topic (REMSH and RAMSES II). It also bears reminding that the citizens' relationship with the EU and "Europe" became particularly sensitive on the occasion of the debates on the draft European constitution. The interest in "citizens", which transpires from the FP6 calls, can be understood in this light. More importantly, in a context that made the EU's need for legitimisation more pressing, supporting scientific projects suggesting that Europe and/or the (enlarged) EU is/are the result of a (long) historical process underpinning a "European identity" may have been seen as a way to foster this legitimisation - as the European Commission's support to the writing of European integration history had until then done for a EU with more limited borders. Indeed, the evaluation of FP proposals is not only based on scientific criteria, but also, importantly, on their "added value to the EU", and FP6-funded projects were in particular invited to address issues connected to the relation between EU citizens and institutions (European Commission, 2002: 47, 62). Regarding historical projects, this past-oriented, but also future-oriented financing policy replicates a symbolic element of the formation of nation-states and largely contributes to raising the question of its particularities, in particular in terms of the establishment of European research networks.

As for the scientific field, heightened research by human and social scientists on Europe and its history has doubtless had an effect on the design of calls. Since the late 1980s, other funders such as national ministries of culture and education or foundations (including the European Science Foundation, managed by different national scientific organisations) have indeed supported projects adopting a wide definition of "European history" in terms of periods under consideration and of approaches - many of them led by international networks (Le Boulay, 2014: 189-191). The access of social scientists to the FPs and these Programmes' new funding policy towards history marked the expansion of the Commission's support to these existing approaches. Historians such as the Italian Luisa Passerini, a EUI professor who had already published a book (1999) questioning "Europeanness" and love, or the German social historian Jürgen Kocka, the co-founder of Berlin's Zentrum für Vergleichende Geschichte Europas (Centre for Comparative History of Europe) in 1998, which has organised international conferences, were able to obtain grants from the Commission through the FPs. The former developed a European gender history with her GRINE network (2001-2004). The second became the coordinator of the CiSoNet project on European civil society (2003-2005). In that sense, the new FPs' calls pertaining to history (and the international exchanges they entail) did not "create" scientific questions ex nihilo - or even a new form of knowledge production (international networks). They reflected scholars' concerns, in particular those of historians who had tried to form international scientific networks on "Europe" in order to contribute to a 
new form of history aimed at overcoming "methodological nationalism" - meaning "the assumption that the nation/state/society is the natural social and political form of the modern world" (Wimmer and Glick-Schiller, 2002: 301) as well as the resulting inclination to limit social science research to one nation-state.

Hence, even if the FPs largely aim at supporting projects with an impact on EU issues, they are not disconnected from ongoing scientific debates. The link between the FP policy and scholars should however be further analysed: not just by examining the case of the scholars who have been appointed as experts by the European Commission and FP-funded teams, but also by addressing the question of the scholars who did not obtain funding. The latter actually offers more potential to examine conflicts and power relations. I will firstly highlight the two main impacts of this new policy on researchers, on application strategies and on the scientific debate on "European history". The feedback effect of this debate on FP7 and H2020 will then be questioned, shedding light on how scientific activities and the EU's funding policy for European history shape each other (even beyond the formal process of recourse to expertise) as well as on the confrontation of official and non-official representations of Europe at European level.

\section{The funding policy's impact on academics, between strategies to fit the FPs' expectations and heightened controversies}

By offering a considerable number of financially highly attractive grants under the FPs, the EU and the Commission in particular, has become a crucial actor in the research world. As a result, the FPs' functioning affects the activities of researchers. General impacts such as the increasing transformation of scientific activity into a contractual exchange between ordering party and providers, mounting managerial constraints, and incentives for research laboratories to merge in order to be more competitive have already been highlighted (Kustosz, 2012). I will focus here on how FPs affect work on the past, especially the shaping of what Astrid Erll (2011: 8) calls "transnational networks of memory" and the development of European narratives. In addition to defining relevant research objects, the FPs impose special requirements for obtaining grants within the thematic priorities. Some of them are formal, concerning especially the composition of the teams, which should be broad, international, and interdisciplinary. Other expectations are not formally stated, but can be pinpointed by examining the funded networks.

During FP5, having a close relationship with the European institutions, especially the Commission, was crucial. This is how the EI HISTORY network was able to receive subsidies, even though it was solely managed by the "Liaison Committee" and thus did not match the requirement of interdisciplinarity. Two of the three other history-based networks supported under FP5 in 2001 included historians working at the EUI - the SERVANT PROJECT with Regina Schulte and the GRINE project, led by Passerini. Later, however, relationships with the institutions would no longer suffice. Within FP6, the "Liaison Committee", in particular, had to comply with the requirements concerning the team's composition. Its members first failed by applying for a grant before they became part of the EU-CONSENT network, in which they had to team up with political scientists (Loth, 2009, personal communication) - since all following history-based projects funded under the FPs' thematic priorities were interdisciplinary, this confirms that this scheme not only stimulates exchanges beyond national borders, but also cooperation between different disciplines.

The historical view expected by the FPs is apparent in the texts of the calls, but also, and arguably even more so, in the projects' presentations and reports. As highlighted earlier, almost all identified projects addressed a European question. Many of them even stressed their contribution to the study of Europe in their title (cf. Table 1). This surely means that this funding 
system was particularly attractive to specialists of European history. These were more likely to benefit from these grants than their colleagues who worked on other topics. I have actually mentioned several historians participating in funded networks who had worked on European history before. However, because of the considerable sums involved, these subsidies could also encourage researchers, in particular historians, to start working on European topics, or at least to reconsider historical questions in a European perspective in order to apply with a chance of success - even if "Europe" was not their initial research object. Strategic choices of research topics are indeed among the repercussions of funding systems based on thematic calls in the academic world (Hubert and Louvel, 2012: 18). In response to a call on "Histories and Identities - Articulating National and European Identities" within FP7, a project on slavery in "European histories and identities" (EURESCL) whose coordinator, the French historian Myriam Cottias, was specialised in the French Antilles (CNRS, n.d.), was for instance successfully submitted. ${ }^{2}$

Additionally, the subsidised projects almost always relate to contemporary issues. Even if the inclusion of academics from non-EU countries suggests a flexible approach to Europe's boundaries - one which is not limited to the EU - the projects very often refer to the EU. EUCONSENT and CULTPAT dealt with the EU's enlargement process. RAMSES II was meant to help conceive the Euro-Mediterranean partnership policy. Within FP7, EUROIDENTITIES explored the factors promoting a "positive identification with the 'European project' by ordinary citizens [which] is crucial for the long-term success of the European Union" (project presentation). That these subsidised projects were portrayed as useful in their presentation and reports intended for the European Commission shows the importance, for social scientists who seek out European funding (even when they work on historical projects), to associate their research topic with contemporary EU issues. This confirms the increasingly pressing call for academics to have their research meet a socio-economic demand and to provide solutions to societal problems, a particularly significant concern in the case of the FPs (Kustosz, 2012: 27).

In this regard, the aforementioned prominence of "European identity" in the projects is partly due to the calls for proposals, but also reflects incentives to be socially useful. It is doubtless less easy for historians or other scientists working on historical subjects than for jurists, economics, political scientists and sociologists who work directly on contemporary issues to convince funders that they can help the European institutions shape and legitimise political decisions. The concept of "identity" gave them an opportunity to build a bridge between past and present. In order to receive funding, even specialists in the history of international relations such as the members of the "Liaison Committee", who did not usually use such concepts, mentioned "European identity" (European Commission, 2003: 259).

Crucially, the FPs' impact on academics cannot be grasped only by looking at funded projects. Considering that around 80\% of the applications are rejected (Kustosz, 2012: 27) - and that many scholars do not even try to obtain FP funding - the stances of the academics who are not financed by this scheme should also be examined. Since the list of unsuccessful applicants cannot be consulted, I focus on those of who I became aware of through my research on controversies surrounding the EU memory policy. By promoting specific approaches to European history, the FPs indeed played a significant role in the emergence of these controversies. Historians whose approach does not match the European Commission's view of history and who did not obtain grants have particularly taken a critical look at the European research policy and its instruments, and are particularly relevant to consider.

The Frenchman Jean-Frédéric Schaub notably submitted a funding application for a research project entitled "Rethinking the history of Europe" (Repenser l'histoire de l'Europe: EurHist) under FP6, within the topic "CITIZENS-2002-7.1.3 - New perspectives on European History". 
The application was rejected and CLIOHRES.NET was selected instead. Schaub then denounced "the complete unsuitability of the Network of Excellence 'instrument' for quality research practices" ("L'inadaptation complète de l' 'instrument' Network of Excellence aux pratiques de recherche de qualité", 2011, personal communication). It is worth noting that EurHist included a research subgroup led by famous historians from several European countries, who were specialised in the 20th century (especially the dark periods thereof). They included the French historian Henry Rousso, specialist of the Second World War and director of the Institute for the History of Present Time in Paris (Institut d'histoire du temps présent) from 1994 to 2005, as well as two German historians from the Centre for Contemporary History of Potsdam (Zentrum für zeithistorische Forschung) - Konrad Jarausch, co-director between 1998 and 2006, a specialist of the history of Germany, and Thomas Lindenberger, deputy director between 2007 and 2008, a specialist of Communist regimes.

After the rejection of the EurHist application, the project was abandoned, but the subgroup dedicated to the twentieth century continued on its own under the name "European Network for Contemporary History" (EurHistXX). Its members were united by hostility to the EU's view of history. In a book described by Rousso (2011, personal communication) as a "manifest", Jarausch and Lindenberger (2007) faulted the draft European constitution for conjuring up "the culture and history of the European peoples" without "mention of national conflicts, ethnic cleansing, world war and genocides". (p. 2). While European integration is often presented as a remedy to the Holocaust and its atrocities, Rousso (2007) noted that the intention of the EU founders was rather "to eradicate the economic and political causes of the two world wars".(p. 33). Furthermore, while the EU institutions try in this frame to enforce a unified European memory, in particular of the Holocaust (Droit, 2007; Gensburger, 2008), Jarausch and Lindenberger (2007) argued that "Eastern and Western Europeans still are [far] from establishing a 'common memory culture."'(p. 3).

Their criticisms were also addressed to the specialists of contemporary history who have been trying to write a European history. They even denounced the "Treitschke temptation to justify the integration process by constructing a European master narrative" (p. 2). Since the nationalist and anti-Semitic Heinrich von Treitschke, Prussia's official historian, is seen in Germany as a figure of subservience to political power, this was a vehement criticism. While the FPs offer scholars the opportunity to secure funding, gain exposure and overcome "methodological nationalism", they pose a risk of conflicting with the academic requirement of independence from political demands, and, especially for historians, the rejection of teleological narratives.

However, Jarausch and Lindenberger (2007) did not give up on "fostering a transnational dialogue about overarching sources, methods, and themes" (p. 2). In reaction to the fact that "Instead of doing research on major catastrophes of the first half of the century in a transnational perspective and understanding the Cold War as the division of Europe, most contemporary historians continue to operate within a national framework" (p. 6), the EurHistXX network proposed writing a contemporary history of Europe that did not underestimate conflicts, and "demythologizing European modernity and nationhood rather than mythologizing the bureaucracy of the EU" (p. 17).

The FPs have thus not only led researchers to work on European history in accordance with the European Commission's expectations. They have also contributed to stimulating some of them to strengthen the debate on EU memory policy and devise alternatives. In other words, the FPs draw the outlines of official, or at least authorised narratives, but also contribute to the development of contradicting, non-official narratives. While the EU fosters some representations of Europe and of history, among others within the FPs, it is not in position to impose a hegemonic narrative. 
The EurHistXX network can be seen as a form of counter-memory, insofar as it was conceived to resist the EU memory policy. However, it should be recalled that its members are far from outsiders. They are widely recognised in their home countries and even internationally - which certainly explains their capacity to weigh in on the debate. While the hierarchical structures at the international level may be the same as at national level - as evidenced for instance by Gayon (2013), who especially underlines the same hierarchical line between economic and social directorates within the OECD, the EU and their Member States -, this shows that this is not always the case. The researchers' positions can differ at national and international level, and even between different international spaces. One can be recognised by peers and invited to many international conferences, and still be in an outsider position within the FPs' funding scheme.

During FP7, a project (MYPLACE) secured funding under the topic "SSH.2010.5.1-1 Democracy and the Shadows of Totalitarianism and Populism: the European Experience" at the expense of the EurHistXX network which had (unsuccessfully) submitted a new application (as well as eight other unsuccessful proposals). Its coordinator, Hilary Pilkington, is not quite as well known as Rousso, Jarausch or Lindenberger, especially within the field of research on totalitarian regimes. Indeed, this British Professor of sociology is specialised in youth and postcommunist societies (University of Manchester, n.d.). It is not possible to know which experts were involved in the selection. Yet, her project matched the call for proposals, which included this topic within an area dedicated to "Participation and citizenship in Europe". It aimed at identifying factors influencing young Europeans' civic and political engagement (or lack thereof), particularly by examining how this "is shaped by the shadows (past, present and future) of totalitarianism and populism in Europe", and it offered solutions to "help young people form sophisticated understandings of the implications of historical events and processes" (project's presentation and final report summary). Furthermore, by claiming to overcome the "reified classification" between post-communist and liberal democratic heritages, it matched the EU memory policy, which promotes a reconciled or even united memory since the 1990s (Droit, 2007; Gensburger, 2008; Mink and Neumayer, 2007), and which has clearly been incorporated in the FP's call, since the topic on totalitarianism primarily aimed at "Overcoming the heritage of the "divided continent".

The EurHistXX network ended up securing funding from the French National Centre for scientific Research (CNRS). Its members gave up on responding to European calls for projects, which Rousso described as "endless time and money wasters which lead to nothing" ("des usines à gaz ruineuses en temps et en argent, et qui ne servent à rien", 2011, personal communication). The idea that research organisations and scholars have more or less eagerly internalised the FPs' constraints, in particular in terms of management and of the injunction to be useful (Kustosz, 2012: 29), deserves to be nuanced. Those who have not obtained funding like the historians specialised in dark periods of European history are particularly vocal critics. Financially enticing as the FPs may be, even some researchers who have benefited from this funding system are not entirely satisfied, in particular because they consider the place of their academic discipline within the FPs too small in comparison with other disciplines (see for instance Kaelble, 2008: 185; Varsori, 2010: 21). Some appointed experts also criticise the FPs' running, in particular the evaluation criteria for projects selection and the fact that this scheme is foremost designed for very large networks (Bundesministerium für Bildung und Forschung, 2011: 2-3). The impact of these criticisms should also be questioned. Have they particularly affected the calls for proposals and the view of history favoured within the FPs? The aforementioned call on "the shadows of totalitarianism and populism" as well as the funded MYPLACE project's focus on "memory" actually suggest a shift. 


\section{Plural identities, negative experiences, memory and heritage issues as ways to alleviate the debates?}

To some extent, FP7 and the ongoing H2020 Programme have certainly ensured the continuity, if not strengthening of the Commission's policy. The projects' value for contemporary debate is still being stressed. Also, and more importantly, the support to projects on European longterm history and "identity" (which characterised a first shift in the European Commission's memory policy following the access of social scientists to the FPs) has not been reconsidered (cf. Table 1). No further research projects strictly focusing on the European integration political process have even been funded, although the overall number of funded projects grew during FP7. Instead, projects dealing with such subjects as identity dynamics in European football (FREE) or "European Responses to the Challenge of Corruption" (ANTICORRP, including historical case studies) drew conclusions on "European integration". By involving non-EU academics and stressing the word "European", they caused confusion between the EU and "Europe". As evidenced by the phrasing "Growing Europe" in the CLIOHRES.NET title, this confusion is not new within FP projects. It reflects an even greater convergence between the EU and continental Europe, which I have already pointed out in the previous examination of FP5 and FP6. Nevertheless, the FP7 saw a genuine, albeit less impressive, second shift. Other transformations should be emphasised, in particular because they reflect the critical debate on "European history".

First, the FP7 marked an effort to put forward a more pluralistic conception of Europe and/or of the EU. The attention to "European identity" was supplemented by an attention to other (especially national and regional) identities and their combinations. The idea of pluralism was not entirely new: during FP6, EUROETHOS examined "a Shared European Pluralistic Ethos". However, this idea was particularly visible within the call "SSH-2007-5.2-01 - Histories and Identities - Articulating National and European Identities", under which six networks were funded (cf. Table 1). This focus on internal diversity - introduced in the EU's cultural policy since the 1980s (Calligaro, 2014) and in the EU's motto since 2000 "Unity in diversity" - was however adopted at the expense of the dialogue between EU and non-EU countries. Indeed, no new projects about the Euro-Mediterranean area were funded, and H2020 has seen the return to smaller networks comprising only researchers from EU Member States (and the candidate country Turkey, participating in the CoHERE project).

Secondly, the FPs have increasingly considered negative historical experiences concerning Western and Eastern Europe since 2008 - following a similar shift within other EU and Council of Europe actions (Droit, 2007; Garcia, 2009; Gensburger, 2008) as well as a broader global development concerning the Holocaust remembrance (Levy and Sznaider, 2001). Furthermore, the Western European narrative was based on the uniqueness of Holocaust until the second half of the 2000s. Since then, the European Parliament (as well as the Parliamentary Assembly of the Council of Europe) has incorporated the idea of an equivalence between Nazi and Communist crimes into several resolutions as a result of the actions of anti-communist activists from Eastern European countries (Neumayer, 2019). Projects like MYPLACE, or EUNAMU, part of which addressed narratives developed in museums under fascism and communism regimes as well as presentations (and comparisons) of these regimes in present-day museums, also support this idea.

However, the consideration of negative experiences remained limited, considering that the only project funded under the call on the "shadows of totalitarianism" (MYPLACE) did not give this topic a central place and was ultimately quite optimistic. Indeed, it offered solutions for political commitment by demonstrating the role of young people's relationships to history in shaping 
political attitudes and the role of schools and museums in shaping these relationships. Admittedly, other projects did discuss negative experiences. Yet, in several of them as well, a somewhat optimistic, forward-looking perspective transpires. EUNAMU aimed to provide "recommendations on how national museums can be mobilized [...] for increased social cohesion and international understanding" (final report). CRIC, on the destruction of cultural heritage during conflicts, mainly focused on the reconstruction of heritage and identities. Another network, EUBORDERSCAPES, examining the concept of "borders" under the coordination of the Finnish Professor of regional and border studies James Scott, was doubtless less optimistic and more critical towards the EU, even if it also offered solutions. Its final report began by mentioning "Dramatic situations at and around Europe's borders" as well as "Europe's own contradictions and failures". It even stated: "The promises of a borderless Europe, a political community built on solidarity and a pan-European liberal open society appear to be succumbing to fear, xenophobia, opportunism and, in some cases, sheer ignorance." However, subsidies are not based on final reports. The project's presentation, promising to "analyse the evolving concept of borders in terms of a mutually linked emergence of 'post-national', 'post-colonial', 'post-modernist' and 'post-Communist' strands of inquiry", was certainly less critical.

Lastly, FP7 and H2020 have been characterised by growing numbers of projects addressing "memory", "heritage", or both, ${ }^{3}$ within the frame of specific or non-specific calls (cf. Table 1). These notions, like the concept of "identity", allow scholars to build a bridge between past and present and to emphasise the usefulness of historical research. For example, by addressing the memorial aspects of slavery, EURESCL tackled the contemporary issue of the integration of Afro-descendants in former colonial powers. "European memory" and "European heritage" are nevertheless more often highlighted. ${ }^{4}$ Despite the attention on plural identities, the search for a common denominator persists, even if it mostly remains vague, whether it is called identity, memory or heritage. The final report of the CRIC project, for instance, not only mentions "discrepant historic narratives", but also the "European cultural heritage" - a phrase the European Parliament began using in the 1970s (Calligaro, 2014: 65) - as well as "a shared heritage as a basis for a shared future".

Nevertheless, the three transformations observed - the growing attention to plural identities and to negative experiences of the past, and the use of the concepts of heritage and particularly of memory - may be seen as ways to respond to criticisms of the EU memory policy. No, the EU would not stress a "European identity" without considering the existence of other identities. No, it would not neglect the dark aspects of history and the past of Eastern European countries. As to the support to projects on "memory", it reflects not only the rise of memory studies since the end of the 20th century (Winter, 2012), but also the momentum of research on representations of European history since 2000 (Le Boulay, 2014: 408-409). This allows specialists of this history to distance themselves from the EU memory policy amid mounting controversy, in particular by shifting the attention towards the writing of European history rather than towards this history itself. In that sense, the FPs have been influenced by the reactions and scientific innovations of the researchers who launched European memory studies, of academics like Jarausch, Linderberger and Rousso, who voiced their disagreement with the FPs - and of the academics who more broadly criticised the idea of "European history" or "identity", without necessarily having being involved with the FPs.

The FPs are certainly more open to the influence of researchers than other EU memory policy instruments, including those targeting academics. Apart from these Programmes, the European Commission did not actually reconsider its strategy of promoting European integration history, especially in the framework of the Jean Monnet Chairs, which enhance EU studies teaching. 
The Commission's Secretary-General David O'Sullivan even ordered a multivolume publication on his institution's own history in the early 2000s (Dumoulin, 2014), thereby resisting the new memory policy at work in FPs. In this context, it should be recalled that academics may directly participate in the processes of conceiving calls and selecting projects. During the FP7, one of the thirteen experts of the EAG which assisted the European Commission for the calls on "Socio-economic sciences and humanities" was an historian: the Italian Giulia Calvi, a professor at the EUI and a specialist of early modern European social history. As regards the EAG on "Europe in a changing world" during H2020, the participation of the Polish historian Przemyslaw Urbanczyk, a specialist of "cultural heritage", deserves mention. Many reviewers who have selected projects under this "Societal Challenge" were also specialists of "cultural heritage" or "cultural studies" (DG RTD, Expertise lists, received from a DG official, 2019, personal communication). More importantly, a specific H2020 expert group on cultural heritage composed of academic, public and private actors was mandated to propose an agenda for cultural heritage research and innovation in 2014.

While these expert groups can provide advice on the FP's form and substance, the role of these "insiders" should nevertheless be nuanced. Their decisions are non-binding and the European Commission retains the right of initiative. They are also appointed on the basis of their area of expertise, which should match the FPs' predefined priorities. H2020 does not only address the notion of "cultural heritage" because specialists of this theme have been involved, but also, more importantly, because the Treaty of Lisbon underscores the importance of cultural heritage, and because 2018 was designated as "European Year of Cultural Heritage" by the European Commission. As regards the selection of research projects, even if several German scholars who were appointed as experts during FP7 described the European Commission representatives as reserved during the "consensus meeting" for discussing proposals, evaluation criteria and their weighting are defined in advance, and selected projects must address a EU political issue as required (Bundesministerium für Bildung und Forschung, 2011: 2-3). Ultimately, the FP remains a scheme that forces scholars to design research under a predefined frame. All of this explains why the FPs' calls for proposals and funded projects pertaining history correspond to the EU memory policy instruments analysed by other authors and why, despite all the transformations observed, the general spirit of the memory policy within the FPs' thematic priorities has not fundamentally changed. It still attempts to legitimate the EU by presenting it as a remedy against past divisions and atrocities and by stressing the existence of a European "identity" or "heritage".

Since FP7, the European Commission has delegated the management of part of this scheme (in addition to the thematic priorities on which this article focuses) to an executive agency created in 2007, the European Research Council (ERC). This institution, composed of European Commission members and of a Scientific Council including Commission-appointed researchers, aims at "[allowing] researchers to identify new opportunities and directions in any field of research, rather than being led by priorities set by politicians" (European Research Council, n.d.). ${ }^{5}$ Although its creation can be considered as having been influenced by criticisms of the FPs' functioning, this phrasing evidences the fact that the thematic priorities mainly remain in the hands of the European institutions, especially the European Commission.

\section{Conclusion}

By studying the history-based networks supported by the FPs, this article refines Rigney's (2014) argument that European institutions offer "top-down memory narratives" (p. 353). While various actors play a role in the FPs - the European Commission, which manages and finances them, the European Parliament, which plays a small role in the FPs' conception, the 
EU Member States, from whom the Commission needs an endorsement, the Council of Europe, whose approaches of the past have often inspired the Commission, experts from the private market, and scholars -, this article focuses on the influence of the latter on the calls for proposals and funded researches pertaining to history. More general findings about the FPs' functioning would require analysing additional sources and other topics such as health or environment. Regarding history-based projects, this article shows that, even if the FPs are a very administrative machinery, researchers do significantly influence them. First, scholars conceive and conduct these projects. In doing so, they contribute, even involuntarily, to shaping an official (or rather authorised) view of history - approved by academics and the European Commission. Secondly, quite a few of them influence the conception of the FPs. Upon first glance, the role of the Commission-appointed experts is the most obvious. Nevertheless, their input remains supervised by the Commission. In more subtle ways, pre-existing scientific approaches can affect the FPs too - in this regard, the FPs' thematic priorities are (at least in the field of European history) not really a structure for innovation, but rather one that encourages circulating and expanding on ideas developed elsewhere. Last but not least, researchers who disagree with the EU memory policy may also alter the scheme with their criticisms and alternative networks.

Still, while the FPs are not a plain top-down scheme, they are surely not a horizontal scheme either. This article argues that funded scientific networks on historical topics mainly remain instruments in the hands of the European Commission, used in conformance with the EU memory policy as analysed by other authors. The shifts in the representations which emerge from the FPs should not be overestimated. Despite the attention to a long-term "European history", plural identities and totalitarian experiences, as well as the inclusion of non-EU researchers, the narrative brought forward continues to be used as a legitimisation instrument for the EU. It generally favours an optimistic approach of European integration, minimising the East/West divide and emphasising the existence of a European "identity" or "heritage". In that extent, this article corroborates the fact (highlighted by Kustoz, 2012: 28) that the aim of the EU research policy at work at the FP is less about producing new insights than about supporting the EU's political goals. Along with the competition between academic approaches and the difficulty for researchers to obtain funding, this explains why this scheme remains a contentious subject, and why it not only gives rise to projects within the suggested "official" frames, but also sparks debates on "European history" and "memory", and even non-official, countermemories - which fail to genuinely alter the official frame, despite the involved researchers' prominence in academic circles.

In this framework, one question arises: that of the specificities of the shaping of visions of Europe in comparison with the visions of the nations. To what extent are visions of Europe European or at least transnational? In particular, to what extent do the FPs contribute to the development of a transnational memory space? Insofar as they foster international exchanges within scientific networks which contribute to the formation of representations of the past, they shape a transnational space for the elaboration of memory narratives. Furthermore, these narratives are "transnational memory" narratives in that they attempt to overcome "methodological nationalism" and never focus on a single country. Although a few funded projects are not limited to "Europe", because their scope extends to the Mediterranean area or the former European colonies and/or they include non-European research establishments, Europe remains their main topical framework and the participating establishments remain mainly European (and largely from EU Member and candidate States). In this way, even if scientific international (or European) networks are not a completely new form of knowledge production, their institutionalisation by the FPs contributes - like other such European forms 
of knowledge instruments (Roa Bastos and Vauchez, 2019) - both to shaping representations of Europe and to building a "European space".

The transnational nature of this "space" should however be further questioned. Following the distinction made by the French historian Pierre-Yves Saunier (2004: 111) between the terms international and transnational, the phrase international space might be more relevant. Indeed, funded networks only include national scientific actors, who are not released from their home countries' establishments. Even those who work at the EUI in Florence must go back to their country after a few years. Moreover, the intensity of the international exchanges should be further analysed (for instance by focusing on one or two networks), as very large networks may not be conducive to close interactions. Additionally, the "space" created by the FPs is very fragmented: It does not form a single network, but various networks that do not genuinely interact. Lastly, it cannot be said that the FPs have resulted in the emergence of a European space of "collective memory". The effects of these scientific projects, or more broadly the EU policy memory, in terms of a European "imagined community" deserve further discussion, but the controversies on "European history" clearly demonstrate the absence of a consensus on this history. On the contrary, combining the examination of the FPs and of their criticisms allows to highlight the confrontation of competing visions of Europe (and European history).

A second defining quality of the shaping of representations of Europe - in particular in the memory policies pertaining to "European history" - is its multi-scalar nature. Beyond the variable-geometry of the FP-funded international research networks, which may have a EU, European or global scope, other policies pertaining to "European history" have been implemented at national level, for instance by the German Volkswagen Foundation (Le Boulay, 2014: 380), or at other international levels, for instance globally by the International Holocaust Remembrance Alliance, founded in 1998. At European level, the promotion of "European history" is not exclusively the result of the European Commission's actions (most notably the FPs, the "Europe for Citizens" programme, and the Jean Monnet Activities, mainly dedicated to the European integration process). Within the EU, the European Parliament has also adopted resolutions on "European memory" and initiated the creation of a museum - the House of European History (Neumayer, 2019; Rigney, 2014). Alongside the EU, the Council of Europe has adopted resolutions on European history and promoted the transmission of knowledge on European history, in particular in the fields of education and culture (Garcia, 2009; Le Boulay, 2014; Neumayer, 2019). As highlighted by quite a few authors (including Calligaro, 2014; Gensburger, 2008; Neumayer, 2019), the policies of these actors are entangled. The increasing role of supranational levels in the shaping of memory narratives is combined with circulations between the different scales (de Cesari and Rigney, 2014). In this way, even if the European institutions replicate the symbolic repertoire of state-building (including a flag, an anthem, historical archives, history writing and teaching...), the symbolic building of Europe does not exactly follow the same pattern.

This raises the question of the FPs' place among the memory policies pertaining to "European history" - in other words, the contribution of EU research policy to these policies. While most focus on the dissemination of knowledge and representations on this history (through commemoration days, museums, history teaching at schools or universities, or official statements), the FPs firstly remain an instrument of knowledge production. Ultimately, the funded projects are liable to provide scientific authority to other forms of action. Again, this explains why they tend to spark conflicts.

\section{Notes}


1. I have not included every call for proposals, project presentation and report in the reference list. They can be found on the CORDIS website.

2. For an overview of the achievements of this project, cf. Collain and Cottias, 2012.

3. Only HI-POD, URBACHINA, ANTICORRP and CATCH-EyoU do not highlight one of these notions. Note also the joint funding of projects on the "uses of the past" by the FPs and national organisations within a "Joint Research Programme" from 2015 to 2019 (which are not listed in the Table 1, as they were funded under an ERA-NET action). See the CORDIS website.

4. See the presentations and reports of CRIC, IME, EUNAMUS, FREE on the CORDIS website, as well as CoHERE which uses the terms "European heritages" in the plural.

5. Concerning the ERC, especially the fact that history-based ERC-funded projects also emphasise their relevance for Europe and the EU, see Baier and Gengnagel, 2018: 89.

\section{References}

Andersen J (2017) The European Research Environment. In: Andersen J, Toom K and Poli S, et al. (eds.) Research Management: Europe and Beyond. London: Elsevier, pp. 31-58.

Baier C and Gengnagel V (2018) Academic Autonomy Beyond the Nation-State: The Social Sciences and Humanities in the European Research Council. Österreichische Zeitschrift für Soziologie 43(1):65-92.

Bond L and Rapson J (eds.) (2014) The Transcultural Turn. Interrogating Memory Between and Beyond Borders. Berlin: de Gruyter.

Bundesministerium für Bildung und Forschung (2011) Erfahrungen von Gutachter/innen im 7. FRP. Available

at: https://www.eubuero.de/media/content/NKS_WiG/Ergebnisse_GutachterInnen_online .pdf (accessed 11 June 2017).

Calligaro O (2013) Negotiating Europe. EU promotion of Europeanness since the 1950s. Basingstoke: Palgrave Macmillan.

Calligaro O (2014) From 'European cultural heritage' to 'cultural diversity'? The changing core values of European cultural policy. Politique européenne 3(45): 60-85.

CNRS (n.d.) COTTIAS Myriam. Available at: http://www.esclavages.cnrs.fr/spip.php?article320 (accessed 20 October 2017).

Collain N and Cottias M (2012) Slave Trade Slavery Abolitions and their Legacies in European Histories and Identities: 2008-2012. Main Results. Available at: http://www.eurescl.eu/images/publications/brochureeurescl.pdf (accessed 12 January 2021).

CORDIS' website: Available at: http://cordis.europa.eu (accessed 1 March 2019).

De Cesari C and Rigney A (eds.) (2014) Transnational Memory: Circulation, Articulation, Scales. Berlin: de Gruyter.

Droit E (2007) Le Goulag contre la Shoah. Mémoires officielles et cultures mémorielles dans l'Europe élargie. Vingtième Siècle. Revue d'histoire 2(94): 101-120.

Dumoulin M (ed.) (2014) The European Commission 1958-72. History and Memories of an Institution. Luxembourg: Publications Office of the European Union.

Erll A (2011) Travelling Memory. Parallax 17(4): 4-18.

Erll A and Rigney A (eds.) (2018) Special issue: Cultural Memory Studies after the Transnational Turn. Memory Studies 11(3) 272-385.

European Commission (2002), Participating in European Research. Guide for applicants under the Sixth Framework Programme for European Research \& Technological 
Development (2002-2006). Luxembourg: Office for Official Publications of the European Communities.

European Commission (2003), Key Action Improving the Socio-Economic Knowledge Base. Available at: http://ec.europa.eu/research/socialsciences/pdf/project_synopses/eur20635_en.pdf (accessed 1 March 2019).

European Commission (2010), Report from the Commission to the European Parliament and to the Council. The memory of the crimes committed by totalitarian regimes in Europe, Brussels, 22.12.2010 COM(2010) 783 final.

European Research Council (n.d.) Mission. Available at: http://erc.europa.eu/about-erc/mission (accessed 1 March 2019).

Garcia P (2009) Vers une politique mémorielle européenne ? L'évolution du statut de l'histoire dans le discours du Conseil de l'Europe. In: Frank R et al. (eds) Building a European Public Sphere. From the 1950s to the Present, Bruxelles: Peter Lang, pp. 179-203.

Gayon V (2013) Homologie et conductivité internationales. L'État social aux prises avec l'OCDE, l'UE et les gouvernements. Critique internationale 2(59) 47-67.

Gensburger S (2008) L'émergence progressive d'une politique internationale de la mémoire : l'exemple des actions publiques de "partage" de la mémoire. In: Auzas V and Jewsiewicki B (eds) Traumatisme collectif pour patrimoine, Laval: Presses de l'Université Laval, pp. 25-41.

Gensburger S and Lavabre MC (eds) (2012) D'une "mémoire européenne" à l'européanisation de la "mémoire". Politique européenne 2(37) 9-154.

Hubert M and Louvel S (2012) Le financement sur projet : quelles conséquences sur le travail des chercheurs ? Mouvements 3(71) 13-24.

Jarausch KH and Lindenberger T (2007) Introduction. Contours of a critical History of Contemporary Europe: A Transnational Agenda. In: Jarausch KH and Lindenberger T (eds.) Conflicted Memories: Europeanizing Contemporary Histories, New York: Berghahn, pp. 1-21.

Kaelble H (2008) Die Europaforschung der Historiker. In: Jaeger F and Joas H (eds.) Europa im Spiegel der Kulturwissenschaften, Baden-Baden: Nomos, pp. 183-203.

Kustosz I (2012) Contractualisation et contrôle de la recherche : une lecture critique du programme-cadre de recherche et de développement technologique de l'Union européenne. Mouvements 3(71): 25-35.

Larat F (2005) Present-ing the Past: Political Narratives on European History and the Justification of EU Integration. German Law Journal 6: 273-290.

Le Boulay M (2010) Investir l'arène européenne de la recherche. Le "Groupe de Liaison" des historiens auprès de la Commission européenne. Politix 23(89): 103-124.

Le Boulay M (2014) Au croisement des mondes politique et scientifique. L'écriture et l'enseignement de l'histoire de l'Europe en France et en Allemagne (1976-2007). PhD Thesis, Université Paris-Dauphine/Humboldt Universität, FR/DE.

Levy D and Sznaider N (2001) Erinnerung im globalen Zeitalter: Der Holocaust. Frankfurt am Main: Suhrkamp.

Littoz Monnet A (2013) Explaining Policy Conflict across Institutional Venues: European Union-Level Struggles over the Memory of the Holocaust. Journal of Common Market Studies 51(3): 489-504.

Mangenot M and Schirmann S (eds.) (2012) Les institutions européennes font leur histoire. Bruxelles: Peter Lang.

Mazé C (2014) La fabrique de l'identité européenne. Dans les coulisses des musées de l'Europe. Paris: Belin.

Mink G and Neumayer L (eds.) (2007) L'Europe et ses passés douloureux. Paris: La Découverte, pp. 195-209. 
Neumayer L (2019) The criminalisation of Communism in the European Political Space after the Cold War. London: Routledge.

Nora P (ed.) (1986) Les lieux de mémoire II. La nation 1. Paris: Gallimard.

Pakier M and Stråth B (eds.) (2010), A European Memory? Contested Histories and Politics of Remembrance. Oxford-New York: Berghahn Books.

Perchoc P (2014) Un passé, deux assemblées. Revue d'études comparatives Est-Ouest 45(3/4): 205-235.

Rigney A (2014) Ongoing: Changing Memory and the European Project. In: De Cesari C and Rigney A (eds.) Transnational Memory: Circulation, Articulation, Scales, Berlin: de Gruyter, pp. 339-359.

Roa Bastos F and Vauchez A (eds.) (2019) L'Archive européenne. Pour une sociohistoire des formes de connaissance de l'Europe. Revue française de science politique 69(1): 7-156.

Rousso H (2007) History of Memory, Policies of the Past: What for? In: Jarausch KH and Lindenberger T (eds.) Conflicted Memories: Europeanizing Contemporary Histories. New York: Berghahn, pp. 23-36.

Saunier PY (2004) Circulations, connexions et espaces transnationaux. Genèses 4(57): 110126.

Sierp A (2014) Integrating Europe, Integrating Memories: The EU's Politics of Memory since 1945. In: Bond L and Rapson J (eds) The Transcultural Turn. Interrogating Memory Between and Beyond Borders. Berlin: de Gruyter, pp. 103-118.

Sierp A and Wüstenberg J (2015) Linking the Local and the Transnational: Rethinking Memory Politics in Europe. Journal of Contemporary European Studies 23: 321-329.

University of Manchester (n.d.) Prof Hilary Pilkington. Available at: https://www.research.manchester.ac.uk/portal/en/researchers/hilarypilkington(0574e3e6-d2c5-42dd-a072-4cc62bc85be6).html4cc62bc85be6).html (accessed 1 March 2019).

Varsori A (2010) From Normative Impetus to Professionalization: Origins and Operation of Research Networks. In: Kaiser W and Varsori A (eds.) European Union History. Themes and Debates, Basingstoke: Palgrave Macmillan, pp. 6-25.

Wimmer A and Glick Schiller N (2002) Methodological Nationalism and Beyond: Nation-state Building, Migration and the Social Sciences. Global Networks 2: 301-334.

Winter J (2012) The Generation of Memory. Reflections on the "Memory Boom" in Contemporary Historical Studies. Canadian Military History 10(3): 57-66.

\section{Author biography}

Morgane Le Boulay is a research engineer in social science at the CNRS/University of Strasbourg Laboratory SAGE (Societies, Actors and Governement in Europe) in France. Her research interests lie in the fields of political sociology of Europe and sociology of knowledge. In 2014, she defended a PhD thesis examining the interactions between historians and history teaching experts from France and Germany and institutions promoting the writing and teaching of European history. More recently, she published an analysis of the Historical Archives of the European Union in the Revue française de science politique. 


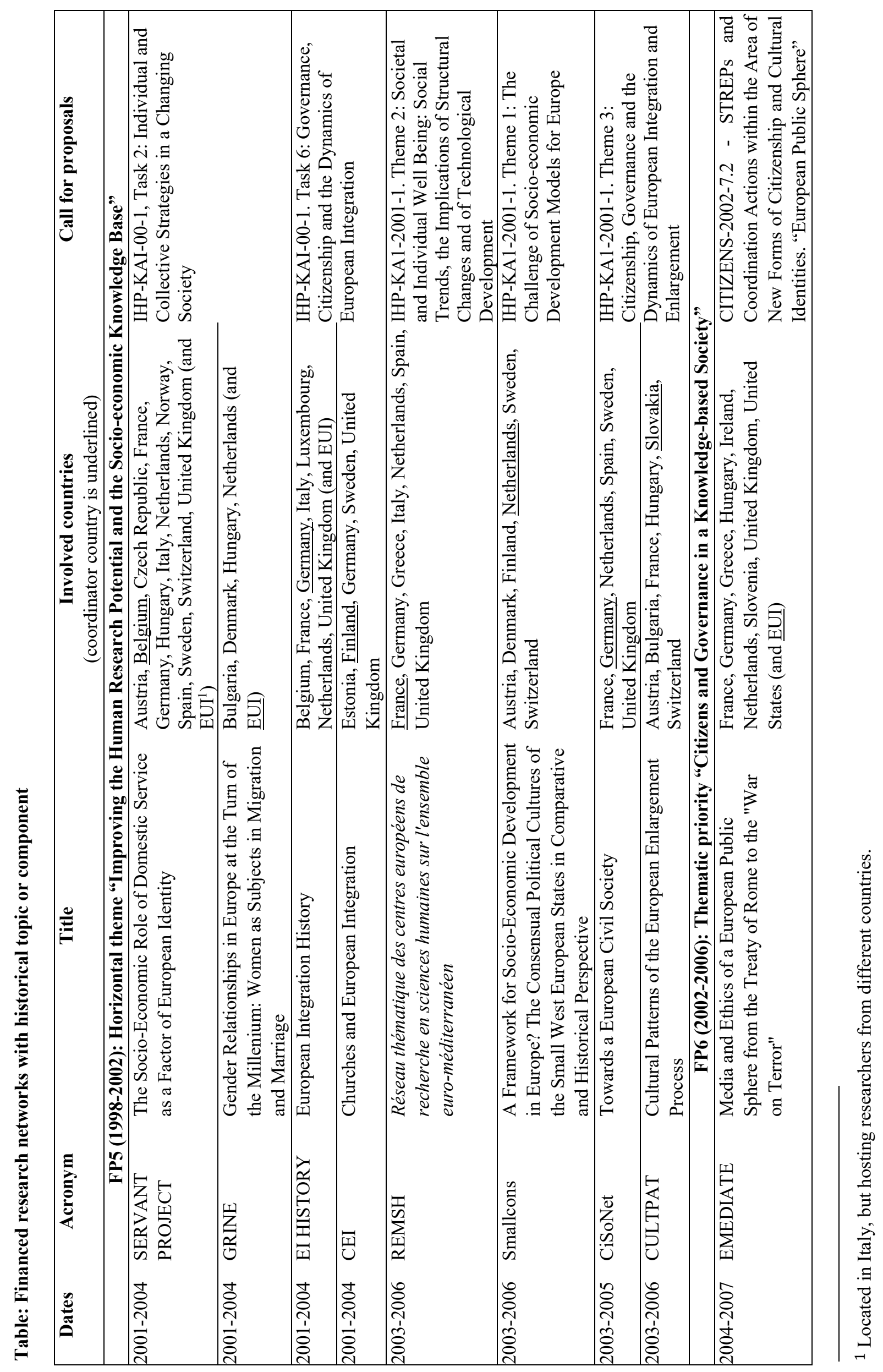




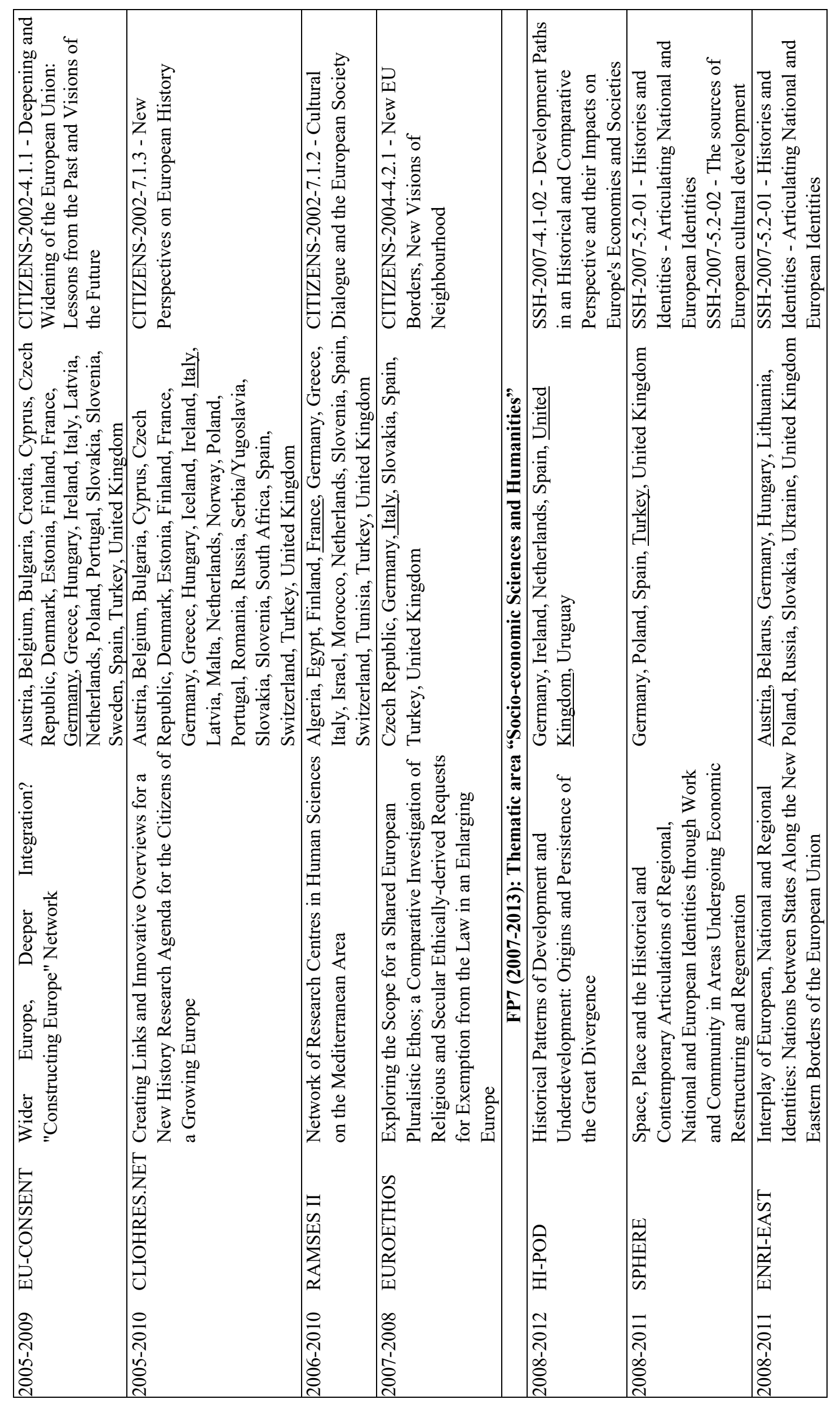




\begin{tabular}{|c|c|c|c|c|c|c|c|c|c|c|}
\hline 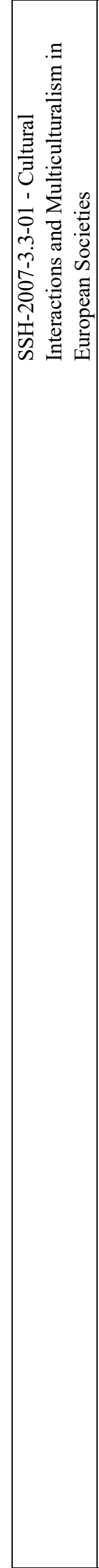 & 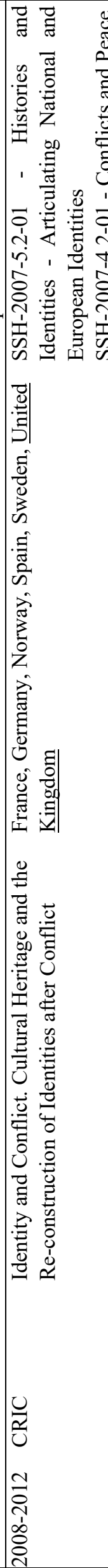 & 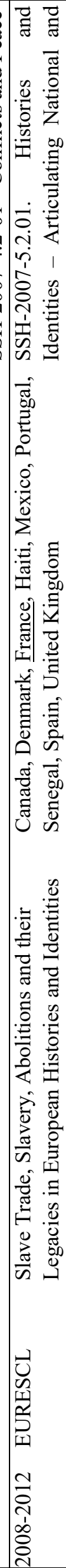 & 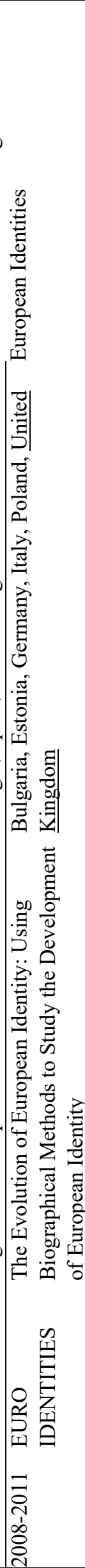 & 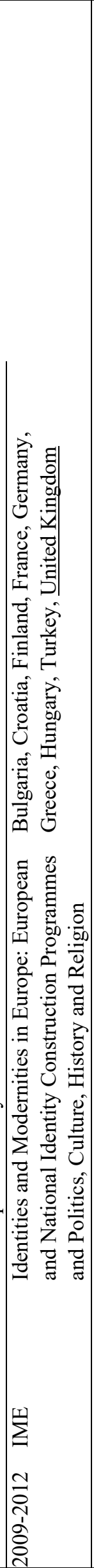 & 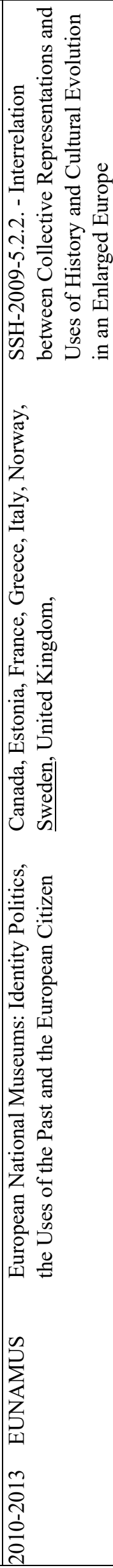 & 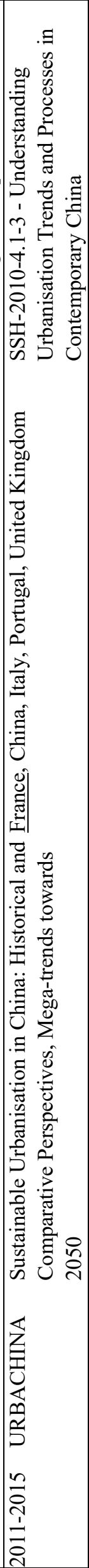 & 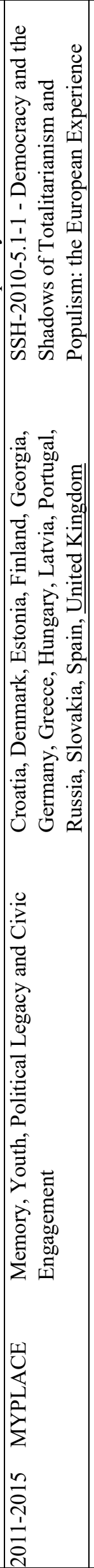 & 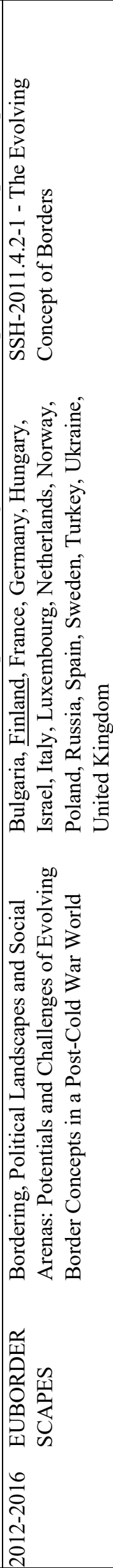 & 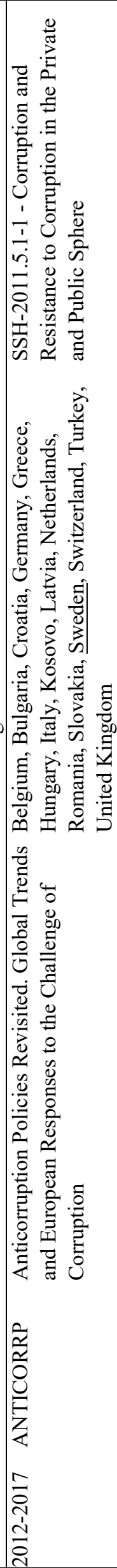 & 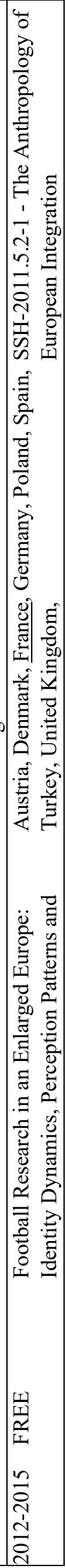 \\
\hline
\end{tabular}




\begin{tabular}{|c|c|c|c|c|c|c|c|c|c|}
\hline 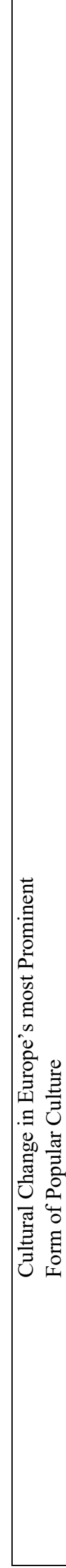 & 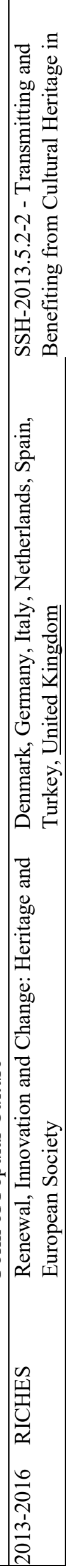 & 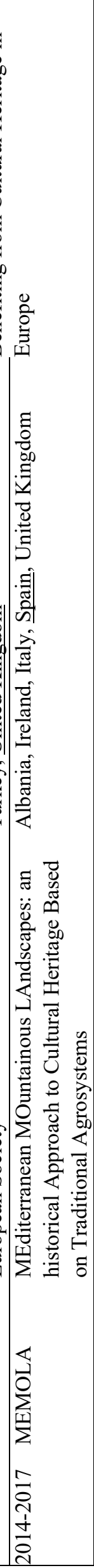 & 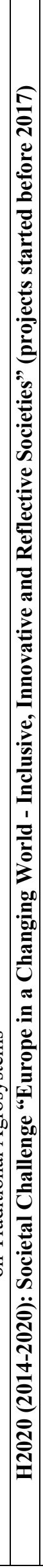 & 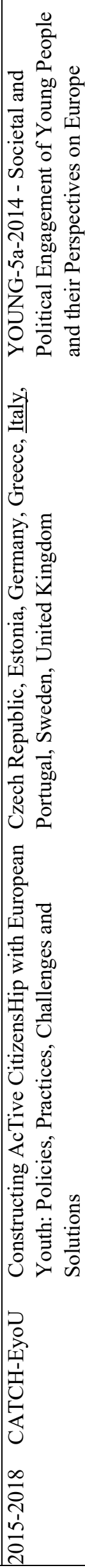 & 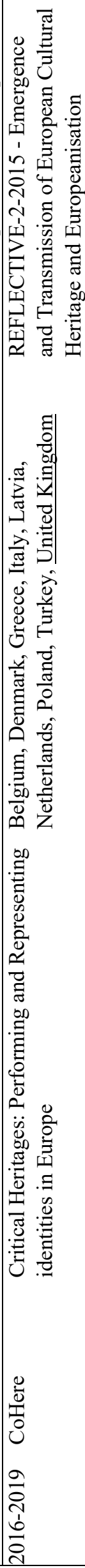 & 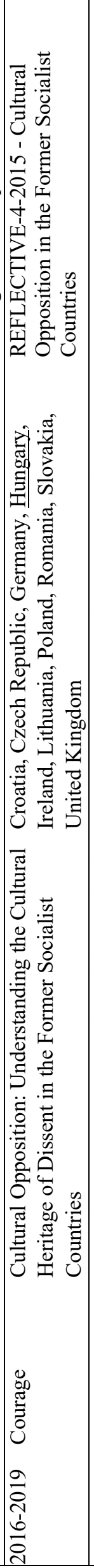 & 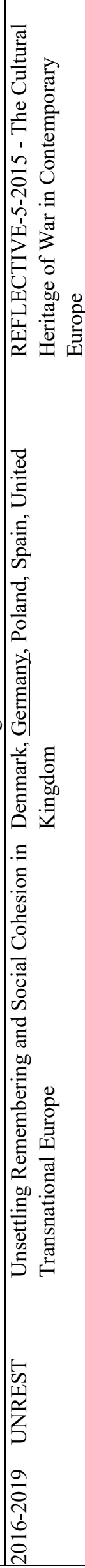 & 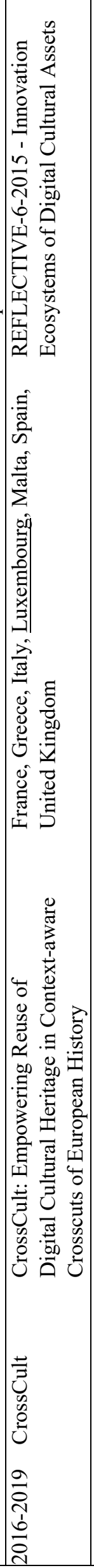 & 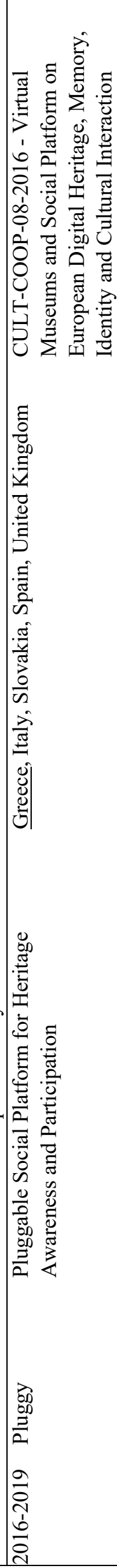 \\
\hline
\end{tabular}

